\title{
Antagonistic and growth-promoting potential of multifarious bacterial endophytes against Fusarium wilt of chickpea
}

Annie Khanna ${ }^{1}$, Kushal Raj ${ }^{*}$, Pankaj Kumar ${ }^{2}$ and Leela Wati ${ }^{3}$

\begin{abstract}
Background: Chickpea is the most important legume crop in India, and its productivity is significantly lowered due to biotic constraints such as wilt caused by Fusarium oxysporum f. sp. ciceris. Endophytes help plants to thrive better under stress conditions by regulating plant hormones and inducing systemic resistance. The aim of the present study was to identify chickpea root bacterial endophytes having antagonistic ability for the management of the Fusarium wilt.

Results: Twenty endophytic bacterial strains were isolated from the susceptible and resistant chickpea cultivar, amongst which 35\% bacterial endophytes gave positive results for siderophore and $15 \%$ isolates were HCN producers, whereas 55\% showed good growth on ACC-supplemented medium. Based upon 165 rRNA phylogenetic analysis, efficient endophytic bacterial isolates CRBE1, CRBE3 and CRBE7 were identified as Priestia megaterium, Brucella haematophila and Microbacterium paraoxydans, respectively. Bacterial endophyte CRBE7 and CRBE3 showed pronounced antagonistic activity against Fusarium oxysporum f. sp. ciceris under in vitro conditions. Inoculation of chickpea with isolated bacterial endophytes alone and in combination through seed priming resulted in significant biocontrol activity against Fusarium wilt of chickpea under screenhouse conditions. Biopriming of chickpea seeds alone with CRBE3 and as consortium of CRBE3 + CRBE7 upsurged the phenol content in susceptible and resistant chickpea varieties JG 62 and $\mathrm{HC} 3$, which indicated the role of promising endophytes as potential bio-agents under in vivo conditions.

Conclusions: Chickpea root bacterial endophytes Priestia megaterium (CRBE1), Brucella haematophila (CRBE3) and Microbacterium paraoxydans (CRBE7) exhibiting antagonistic activity could be incorporated in integrated disease management module against Fusarium wilt of chickpea.
\end{abstract}

Keywords: Bacterial endophyte, Chickpea, Fusarium wilt, Priestia megaterium, Brucella haematophila, Microbacterium paraoxydans

\section{Background}

Chickpea (Cicer arietinum L.) is an important leguminous crop. India is the largest chickpea producer in the world with production volume amounting to nearly ten million metric tonnes (https://www.statista.com/stati stics/722203/chickpeas-production-volume-by-count

\footnotetext{
*Correspondence: kushalraj@hau.ac.in; LWKRAJ@gmail.com

1 Department of Plant Pathology, College of Agriculture, CCS Haryana

Agricultural University, Hisar, Haryana Pin 125 004, India

Full list of author information is available at the end of the article
}

ry-worldwide/). Chickpea productivity is significantly lowered due to biotic stresses, namely wilt caused by Fusarium oxysporum f. sp. ciceris in various regions of the world including India (Jiménez-Díaz 2015). In India, the disease was reported to reduce chickpea production annually by $10-15 \%$ (Dubey et al. 2007), reaching up to $70 \%$ in years of severe outbreak (Halila and Strange 1996).

Endophytic bacteria are known to promote the plant growth by producing siderophores, auxins, phytohormones and enzymes, nitrogen fixation, solubilizing phosphate, releasing ammonia or by supplying essential 
vitamins to plants (Saini et al. 2015). These microbes provide protection against phyto-pathogens mediated by volatile metabolites including hydrogen cyanide and ammonia, iron acquisition by siderophores production of antibiotic, exopolysaccharides, production of cell wall degrading enzymes and antioxidant enzymes like superoxide dismutase, catalase, peroxidase and phenols (Nagpal et al. 2021).

Identification and use of PGPR along with antagonistic properties against plant pathogens were essential and promoted throughout the world for sustainable crop production. Kumari and Khanna (2018) reported 74.5\% and $70.3 \%$ reduction in Fusarium wilt incidence in chickpea genotypes GPF-2 and JG-41, respectively, on bacterial inoculation along with production of siderophore, $\mathrm{HCN}$ and plant growth hormones. Bacillus megaterium significantly reduced the fungal growth of $F$. graminearum in wheat (Pan et al. 2015) and triggers salicyclic acid-dependent resistance in rice to mitigate the disease caused by $F$. proliferatum (Cheng et al. 2020). The biological control of Ralstonia solanacearum, incitant of potato wilt disease through endophytic bacteria Bacillus, Pseudomonas and Microbacterium was observed by Bahmani et al. (2021). Despite adequate knowledge on potential growth-promoting bacterial endophytes in chickpea, the studies on their bio-control potential against F. oxysporum f. sp. ciceris are scanty. Moreover, use of indigenous endophytic bacteria possessing plant growth traits along with bio-control potential is the best eco-friendly and ecologically efficient approach within the framework of integrated disease management. Therefore, the present investigation aimed to exploit the bacterial symbionts that possessed both plant growth-promoting and antagonistic ability, as potential biocontrol agents.

\section{Methods}

\section{Isolation of endophytic bacteria}

Endophytic bacteria were isolated from the roots of chickpea cultivars, viz. HC 5 (resistant) and JG 62 (susceptible) grown in Fusarium wilt infected plot at Pulses Section, Department of Genetics and Plant Breeding, CCS Haryana Agricultural University, Hisar, India (Latitude: $29^{\circ} 14^{\prime} 92^{\prime \prime} \mathrm{N}$, Longitude: $75^{\circ} 72^{\prime} 17^{\prime \prime} \mathrm{E}$ and Altitude: $215 \mathrm{~m}$ AMSL). The standard protocol for isolation of endophytic bacteria given by Sangwan et al. (2021) was followed. Roots were washed with running tap water and surface sterilized sequentially in $75 \%$ (v/v) ethanol for $2 \mathrm{~min}, 2.6 \%(\mathrm{w} / \mathrm{v})$ sodium hypochlorite solution for $5 \mathrm{~min}$ and $75 \%(\mathrm{v} / \mathrm{v})$ ethanol for $1 \mathrm{~min}$ followed by thorough five to six times washing with sterile distilled water. For isolation of bacterial endophytes, $1 \mathrm{~g}$ root was crushed in pestle and mortar with $10 \mathrm{ml}$ sterile distilled water to get uniform paste and allowed to settle down for 15-20 min.
The supernatant was further diluted five times in $10 \mathrm{ml}$ water, and approximately $10 \mu \mathrm{l}$ was used for streaking on nutrient agar plates and incubated at $28 \pm 1{ }^{\circ} \mathrm{C}$ for 3 days. The colonies of bacterial endophytes were characterized based on visual observations, purified using streak plate technique and maintained on nutrient agar slants at $4{ }^{\circ} \mathrm{C}$ for further study.

\section{Plant growth-promoting abilities of bacterial endophytes}

Isolated bacterial endophytes were tested for their plant growth-promoting abilities, namely siderophore production, hydrogen cyanide $(\mathrm{HCN})$ production, 1-aminocyclopropane 1-carboxylic acid (ACC) utilization. Siderophore production of isolated bacterial endophytes was identified using Chrome azurol S assay (Schwyn and Neilands 1987). From each log phase grown culture, $10 \mu \mathrm{l}$ was spotted on the siderophore plates and incubated at $28 \pm 1{ }^{\circ} \mathrm{C}$ for $3-4$ days. The presence of siderophore was indicated by the formation of yellow halo zone around the colonies. The production of hydrogen cyanide was detected after $72 \mathrm{~h}$ of incubation of bacterial isolates in King's $B$ broth at $28 \pm 1{ }^{\circ} \mathrm{C}$, using alkaline picrate soaked filter paper fixed inside the test tube. A colour change from yellow to reddish brown was noted as indication of weak, moderate or strong cyanogenic potential. (Alstrom and Burns 1989).

For ACC utilization, the minimal medium (Dworkin and Foster 1958) supplemented with $2 \mathrm{mM}$ ACC was prepared (Penrose and Glick 2003). A loopful of bacterial endophytes from $48 \mathrm{~h}$ old culture was spotted on ACC supplemented minimal medium plates. Growth of the isolates on ACC and ammonium sulphate amended medium plates was observed after 5 days of incubation at $28 \pm 1{ }^{\circ} \mathrm{C}$. The minimal medium plates having ammonium sulphate were used as control for growth comparison of different isolates.

\section{Isolation of pathogen}

The Fusarium wilt-infected chickpea plants were collected from the wilt infected plot at Pulses Section, CCS Haryana Agricultural University, Hisar, India. The pathogen was isolated from the infected roots of chickpea plants, and culture was identified at Department of Plant Pathology, CCS Haryana Agricultural University, Hisar, India.

\section{In vitro efficacy of bacterial endophytes}

The bacterial endophytes were evaluated for their inhibitory potential against Fusarium identified strain under in vitro following dual culture technique on potato dextrose agar (HIMEDIA M096) plates with four replications maintained for each bacterial isolate. A 5-mm mycelial disk from a one-week-old fungus culture was placed in 
the center of a 90-mm-diameter Petri dish containing PDA medium. The bacterial strain was applied in two opposite streaks at approximately $30 \mathrm{~mm}$ from the fungal plug. The medium plates were incubated at $28 \pm 1{ }^{\circ} \mathrm{C}$, and split growth of pathogen was observed when the control plates were completely filled with test pathogen. The percentage growth inhibition was calculated following the formula of Vincent (1947).

\section{Morphological, biochemical and molecular characterization}

Three bacterial endophytes that exhibited prominent antagonistic activities were morphologically and biochemically characterized as per procedure described in Bergey's Manual of Determinative Bacteriology (Holt et al. 1994). For molecular identification, the $16 \mathrm{~S}$ rRNA region of different isolates was amplified using forward primer (F:5'AGA GTT TGA TCC TGG CTC AG $3^{\prime}$ ) and reverse primer (R:5'AAG GAG GTG ATC CAG CCG CA 3') (Weisburg et al. 1991). The amplified product was sequenced at Biotechnology Laboratory, University of LUVAS, Hisar, Haryana (India). The sequence for all the endophytes was obtained and analysed using BLAST. Identification up to species level was ascertained as maximum homology ( $\geq 99 \%)$ to a type strain sequence in the GenBank. Phylogenetic tree for the available data sets was deduced using the neighbour joining program, MEGA version 11.0.8 (Kumar et al. 2018).

\section{In vivo efficacy of bacterial endophytes and their impact on total phenol content in chickpea plants}

The identified Fusarium strain was multiplied on potato dextrose broth, while the bacterial endophytes, CRBE1, CRBE3 and CRBE7 were multiplied in nutrient broth for 2 days at $28 \pm 1{ }^{\circ} \mathrm{C}$ for artificial inoculation. The experiment was conducted with seven treatments, viz. CRBE1 alone, CRBE3 alone, CRBE7 alone, CRBE1 + CRBE3, CRBE3 + CRBE7, CRBE1 + CRBE7 and CRBE1 + CRBE3 + CRBE7, in earthen pots under screen house conditions during crop season 2019-2020 in completely randomized design with three replications. Each pot was filled with five $\mathrm{kg}$ of sterilized sandy soil inoculated with test pathogen for each replication; three pots were maintained. The pathogen was inoculated as soil drench with conidial suspension adjusted to $10^{6}$ conidia/ ml. Seeds of chickpea cultivars, viz. JG 62 and HC 3, were treated separately with $1 \mathrm{ml}$ inoculum of each of the bacterial endophyte independently and in combination. The bacterial suspension was adjusted to $10^{8}$ cells/ $\mathrm{ml}$, and for co-inoculation, the cell suspension of both endophytic bacterial strains was mixed in 1:1 ratio. Uninoculated surface sterilized seeds served as control and four seeds were sown in each pot. The observations on disease incidence were recorded by examining the healthy and disease plants.

Total phenols in root samples at different time intervals were estimated by following the standard procedure (Thimmaiah 2006). A $100 \mathrm{mg}$ of dried root sample was taken, and $10 \mathrm{ml}$ of $80 \%$ methanol was added to it. It was kept in water bath at $80{ }^{\circ} \mathrm{C}$ for $30 \mathrm{~min}$. Five $\mathrm{ml}$ of $80 \%$ methanol was added to the supernatant and incubated in water bath for half an hour. The above step was performed again. The supernatant collected was centrifuged at $6000 \mathrm{rpm}$ for $15 \mathrm{~min}$ and transferred to other clean test tube. After drying the samples completely by evaporation in water bath at $80{ }^{\circ} \mathrm{C}, 5 \mathrm{ml}$ water was added in each test tube and test tubes were vortexed. One $\mathrm{ml}$ of this solution was mixed with $4.0 \mathrm{ml}$ water. This solution $(0.5 \mathrm{ml})$ was transferred to a test tube, and $0.5 \mathrm{ml}$ Folin-Ciocalteu reagent was added to it. It was left for $3 \mathrm{~min}$ followed by addition of $2 \mathrm{ml}$ of $20 \%$ sodium carbonate solution. The absorbance was measured at $650 \mathrm{~nm}$. The amount of phenol expressed ( $\mu \mathrm{g} / \mathrm{g}$ dry weight) in the sample was estimated from the standard curve prepared gradually by taking catechol as the standard phenol content.

\section{Statistical analysis}

Data were analysed statistically after angular transformation using appropriate design (Panse et al. 1978), and the treatments were compared at $p=0.05$.

\section{Results}

\section{Isolation of pathogen}

The Fusarium wilt-infected chickpea plants were collected from the wilt infected plot at Pulses Section, CCS Haryana Agricultural University, Hisar, India. The isolated pathogen from the infected roots of chickpea plants was identified as Fusarium oxysporum f. sp. ciceris, by comparing the morphological and conidial characteristics of the standard culture.

\section{Isolation of endophytes}

Twenty chickpea root bacterial endophytes were retrieved from susceptible and resistant cultivars of chickpea during 2018-2019. Eight bacterial endophyes, viz. CRBE1, CRBE4, CRBE7, CRBE8, CRBE10, CRBE12, CRBE14 and CRBE15, were retrieved from susceptible cultivar JG 62, while twelve bacterial endophytes, viz. CRBE2, CRBE3, CRBE5, CRBE6, CRBE9, CRBE11, CRBE13, CRBE16, CRBE17, CRBE18, CRBE19 and CRBE20, were retrieved from resistant cultivar HC 5.

\section{In vitro efficacy of bacterial endophytes against Fusarium oxysporum f. sp. ciceris}

The twenty endophytic bacteria isolated from chickpea roots were evaluated for their antagonistic activity 
against $F$. oxysporum $\mathrm{f}$. sp. ciceris under in vitro conditions. All the endophytic bacterial isolates were found to inhibit the fungal growth ranging from 14.34 to 69.38\%. Endophytes, CRBE3 and CRBE7 (statistically at par) exhibited growth inhibition of 63.95 and 69.38\%, respectively, followed by CRBE1, CRBE19 and CRBE5 which suppressed the fungal growth by $53.10,51.16$ and 48.06\%, respectively, while the isolates CRBE4, CRBE6, CRBE11 and CRBE12 were the least effective in inhibiting mycelial growth of the test pathogen (Table 1).

\section{Plant growth-promoting attributes}

All the endophytic bacterial isolates except CRBE5, CRBE13, CRBE16, CRBE18, CRBE19 and CRBE20 exhibited at least one or more plant growth-promoting trait. Seven isolates, viz., CRBE2, CRBE3, CRBE4, CRBE7, CRBE8, CRBE10 and CRBE 17, exhibited siderophore production ability, while $15 \%$ endophytes (CRBE1, CRBE7 and CRBE9) were positive HCN producers. The bacterial endophyte CRBE1 showed good growth on ACC supplemented plates, while CRBE2, CRBE3, CRBE6, CRBE8, CRBE9, CRBE11, CRBE12, CRBE14, CRBE15 and CRBE17 showed moderate activities. Venn diagram drawn (Fig. 1) showed the distribution of bacterial isolates with their biocontrol traits. Different traits of bacteria were represented by different coloured circles. The isolates falling within different colours represented the particular trait(s). Three endophytic bacterial isolates (CRBE1, CRBE3 and CRBE7) that showed distinct antifungal activities in vitro against $F$. oxysporum f. sp. ciceris and growthpromoting traits were characterized biochemically and identified at molecular level.

Table 1 Mycelial growth inhibition of Fusarium oxysporum f. sp. ciceris by bacterial endophytes under in vitro conditions

\begin{tabular}{llll}
\hline Isolates & $\begin{array}{l}\text { Mean growth } \\
\text { inhibition (\%) }\end{array}$ & Isolates & $\begin{array}{c}\text { Mean growth } \\
\text { inhibition (\%) }\end{array}$ \\
\hline CRBE1 & $53.10(46.76)^{*}$ & CRBE11 & $14.34(22.13)$ \\
CRBE2 & $24.41(29.57)$ & CRBE12 & $18.60(25.49)$ \\
CRBE3 & $63.95(53.09)$ & CRBE13 & $33.72(35.47)$ \\
CRBE4 & $17.83(24.92$ & CRBE14 & $28.68(32.34)$ \\
CRBE5 & $48.06(43.87)$ & CRBE15 & $25.19(30.06)$ \\
CRBE6 & $15.89(23.46)$ & CRBE16 & $28.68(32.34)$ \\
CRBE7 & $69.38(56.42)$ & CRBE17 & $34.49(35.94)$ \\
CRBE8 & $32.55(34.73)$ & CRBE18 & $24.03(29.31)$ \\
CRBE9 & $31.78(34.28)$ & CRBE19 & $51.16(45.64)$ \\
CRBE10 & $39.14(38.70)$ & CRBE20 & $21.31(27.43)$ \\
C.D. $(p=0.05)$ & $(3.56)$ & & \\
\hline
\end{tabular}

*Figures in the parentheses are angular transformed values

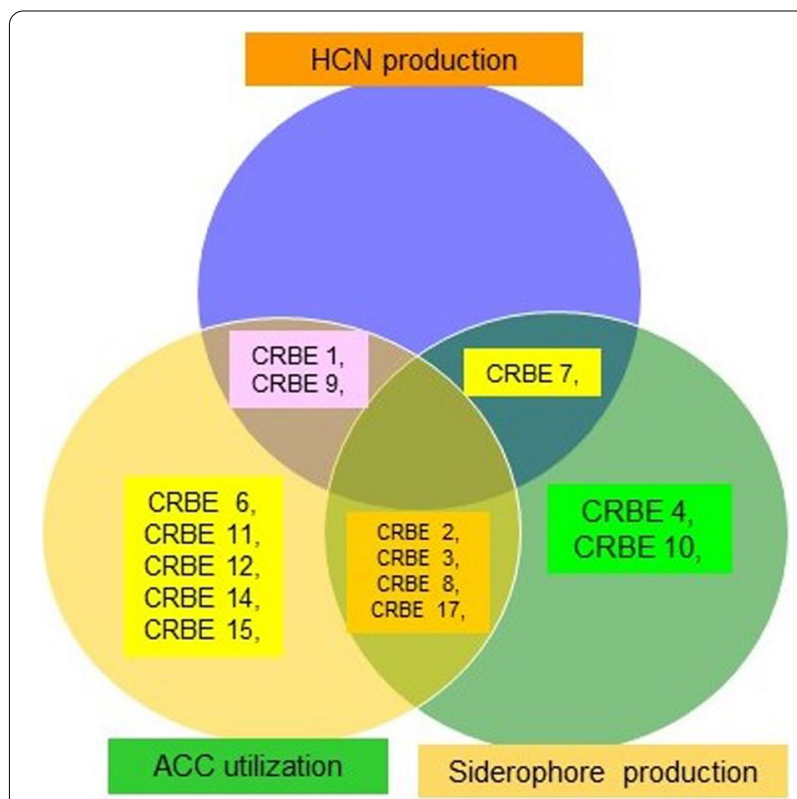

Fig. 1 Venn diagram showing plant growth-promoting traits of chickpea root bacterial endophytes

\section{Morphological, biochemical and molecular characterization of bacterial endophytes}

Based on colony morphology and Gram reaction, isolate CRBE1 was found as a Gram-positive bacterium having flat, smooth and shiny colony surface, while isolate CRBE3 was a Gram-negative bacterium, showing shiny white colour colonies on nutrient agar medium with smooth and flat surface. Isolate CRBE7 was a Gram positive bacterium, and its colonies appeared yellowish on nutrient agar medium.

Based on more than $98 \%$ sequence homology of $16 \mathrm{~S}$ rRNA gene with the gene sequences available in the NCBI nucleotide database, potential endophytic bacterial isolates (CRBE1, CRBE3 and CRBE7) were identified as Priestia megaterium (Accession no. OK482778), Brucella haematophila (Accession no. OK482777), and Microbacterium paraoxydans (Accession no. OK482779), respectively (Figs. 2, 3).

\section{In vivo efficacy of endophytic bacterial isolates against Fusarium oxysporum f. sp. ciceris and effect on total phenol content}

Based on in vitro assay and plant growth-promoting traits, three antagonistic endophytic bacteria CRBE1, CRBE3 and CRBE7 were tested alone and in combination under screen house conditions for their antifungal activity against $F$. oxysporum f. sp. ciceris. Seed priming with cultures of endophytes significantly reduced the disease incidence over control in chickpea varieties, JG 62 and 


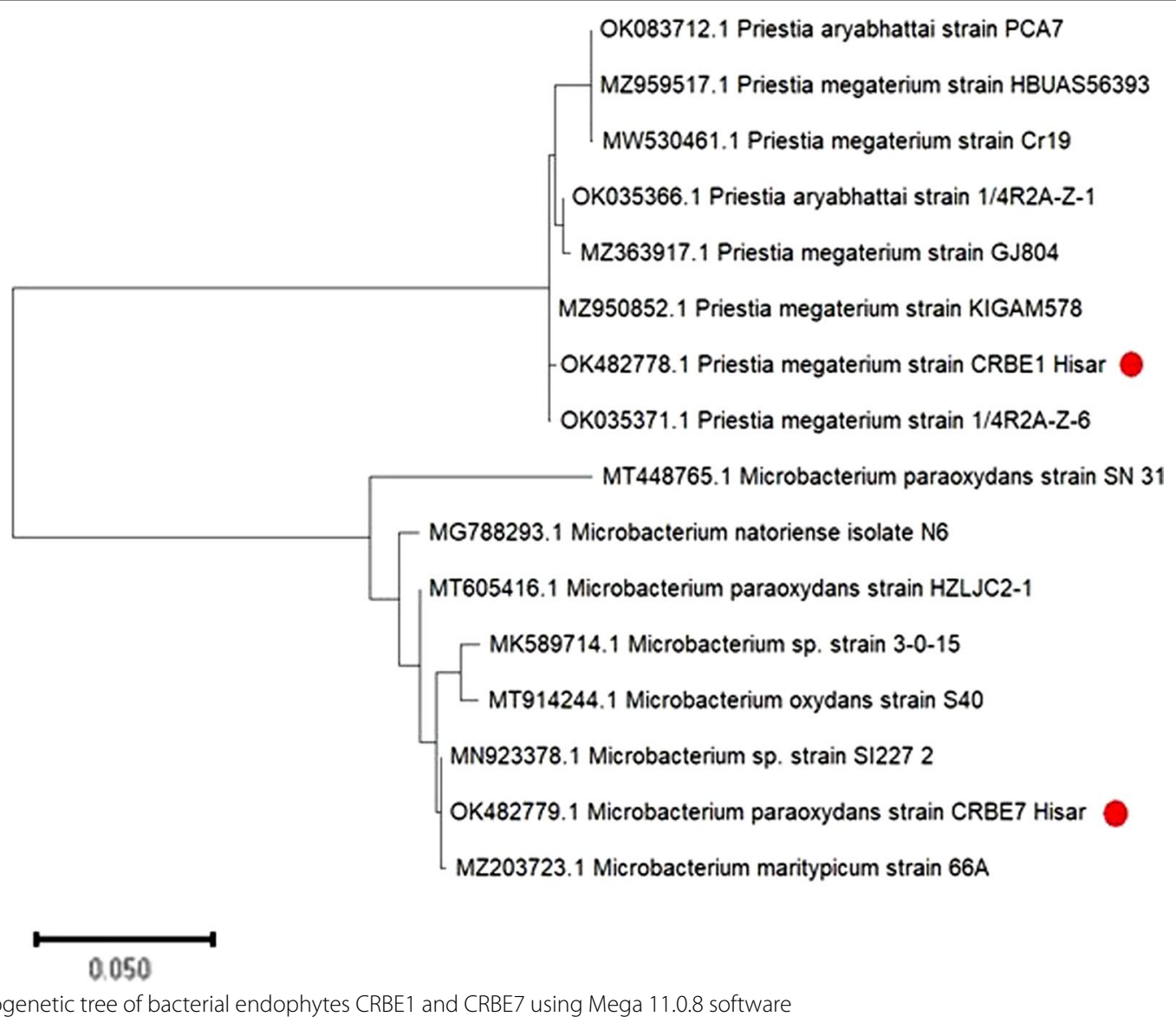

HC 3. Seed priming with CRBE3 (Brucella haematophila) in chickpea variety JG 62 was found to be the most effective in suppressing the wilt incidence from 69.44 to $11.11 \%$, while the other treatments were found to be statistically at par. In resistant variety $\mathrm{HC} 3$, seed treatment with endophyte CRBE3 curtailed the disease incidence from 22.22 to $2.78 \%$ (Table 2). However, when the consortium of endophytes used, their potential antagonistic activity against Fusarium wilt hampered as compared to their alone application in both the varieties.

Plant phenolic compounds play a vital role in plant defence and fluctuation in concentration is observed in response to invading pathogen. In resistant chickpea variety $\mathrm{HC} 3$, maximum mean phenol content, i.e. $366.49 \mu \mathrm{g} / \mathrm{g}$, was recorded on seed treatment with isolate CRBE3 which was significantly higher than the other treatments, while minimum phenol content was recorded in plants after seed treatment with CRBE1. Seed treatment with CRBE1+CRBE7 and consortium of CRBE1 + CRBE3 + CRBE7 was found to be statistically at par with a phenol content of 223.60 and
$228.47 \mu \mathrm{g} / \mathrm{g}$, respectively. There was significant increase in phenol content of chickpea plants of resistant variety $\mathrm{HC} 3$ with the increase in duration of sampling. The maximum phenol content was recorded in the 3rd week of sampling $(299.62 \mu \mathrm{g} / \mathrm{g})$ followed by the $2 \mathrm{nd}$ one, while it was a minimum in the 1st week of sampling. The interaction between bacterial endophytes and duration of sampling was significant. The highest phenol content $(412.70 \mu \mathrm{g} / \mathrm{g})$ was recorded in the $3 \mathrm{rd}$ week of sampling in plants of resistant chickpea variety $\mathrm{HC} 3$ raised from seeds primed with CRBE3 followed by CRBE3 + CRBE7 and CRBE7 alone which were statistically at par (Table 3 ).

Similar trend with respect to phenol content was recorded in susceptible variety JG 62. Maximum phenol content was recorded in plants treated with CRBE3 $(201.56 \mu \mathrm{g} / \mathrm{g})$ followed by CRBE3 + CRBE7 $(168.64 \mu \mathrm{g} / \mathrm{g})$. However, it was significantly lower in chickpea variety JG 62 in comparison with resistant variety HC 3 irrespective of duration of sampling. 


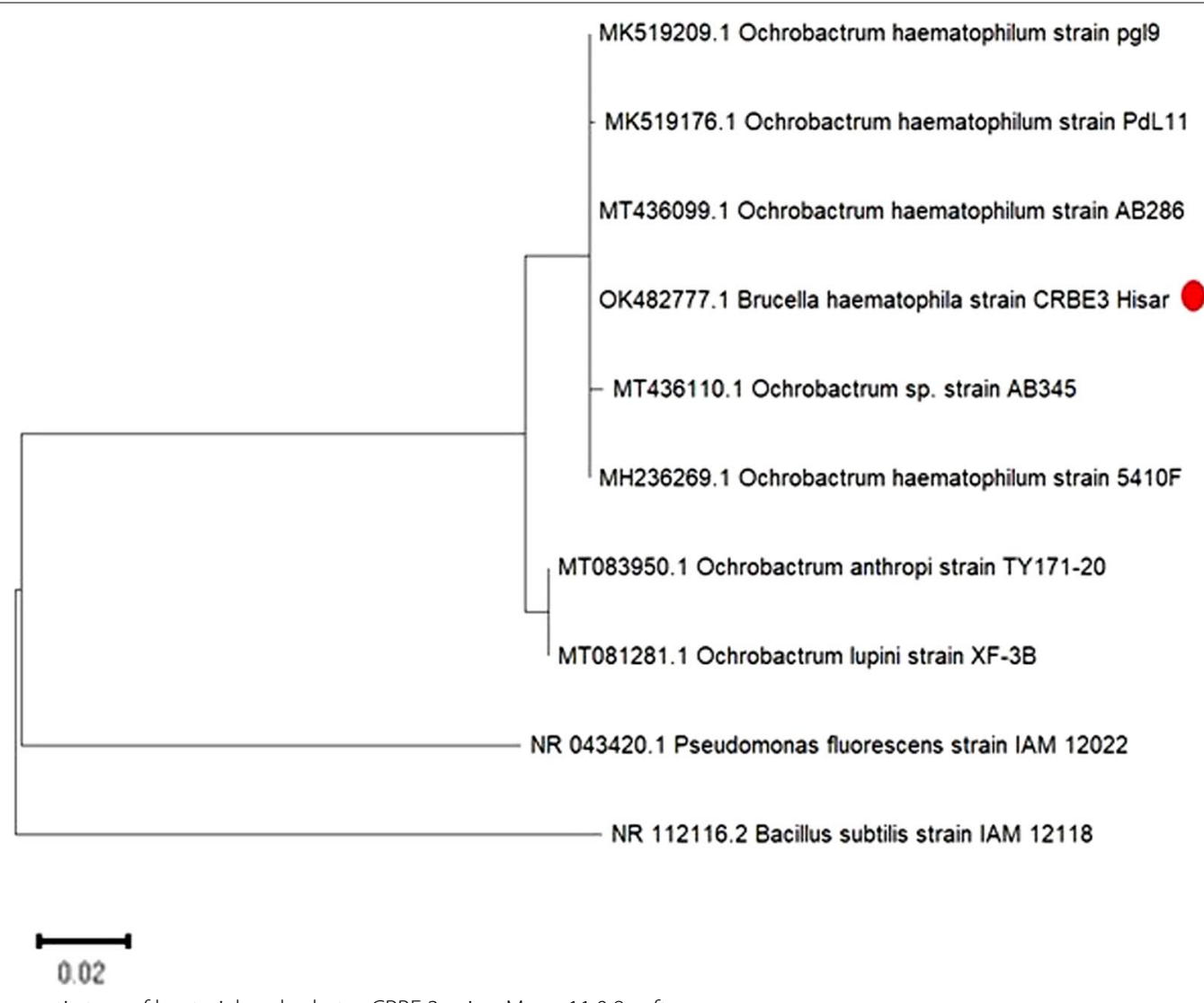

Fig. 3 Phylogenetic tree of bacterial endophytes CRBE 3 using Mega 11.0.8 software

Table 2 Effect of bacterial endophytes on incidence of Fusarium wilt in two chickpea varieties under screen house conditions

\begin{tabular}{lll}
\hline Isolates & \multicolumn{2}{l}{ Disease incidence (\%) } \\
\cline { 2 - 3 } & JG 62 & HC 3 \\
\hline CRBE1 & $27.78(31.74)^{*}$ & $8.33(13.68)$ \\
CRBE3 & $11.11(19.21)$ & $2.78(5.71)$ \\
CRBE7 & $25.00(29.99)$ & $5.56(11.24)$ \\
CRBE1 + CRBE3 & $27.78(31.53)$ & $13.89(21.65)$ \\
CRBE1 + CRBE7 & $33.33(35.14)$ & $11.11(19.21)$ \\
CRBE3 + CRBE7 & $27.78(31.74)$ & $11.11(19.21)$ \\
CRBE1 + CRBE3 + CRBE7 & $30.56(33.50)$ & $13.89(21.65)$ \\
Control & $69.44(56.47)$ & $22.22(28.02)$ \\
CD $(p=0.05)$ & $(6.83)$ & $(12.60)$ \\
\hline
\end{tabular}

* Figures in the parentheses are angular transformed values

\section{Discussion}

Endophytes facilitate plant growth by protecting plants from plant pathogens and increasing its tolerance against various biotic and abiotic stresses (Khanna et al. 2019). In the present study, 20 morphologically distinct endophytic bacteria were isolated from the roots of susceptible and resistant chickpea varieties. Several researchers reported a wide variation in genera of endophytic bacteria from the roots of chickpea (Batra et al. 2020). Maheshwari et al. (2019) revealed the identity of the bacterial isolates as Pantoea agglomerans, B. cereus, B. sonorensis, B. subtilis, P. chlororaphis, Ornithinibacillus sp. and Ochrobactrum sp. Rangeshwaran et al. (2008) identified B. megaterium, Enterobacter agglomerans and other Bacillus sp. from the root endosphere of healthy chickpea plants, while Mukherjee et al. (2020) identified the endophytic bacteria as Bacillus sp., Enterobacter sp., Mixta sp., Pantoea sp., Pseudomonas sp. and Staphylococcus sp. associated with chickpea seed. In the present study, isolate CRBE3 identified as Brucella haematophila, through $16 \mathrm{~S}$ rRNA sequencing exhibited PGP traits, viz. siderophore production and ACC utilization. The reclassification of Ochrobactrum to Brucella based on genome analysis of strain types was proposed by Hordt et al. (2020). Brucella species were isolated from various sources such as the root nodules of Lupinus plant (Volpiano et al. 2019), tomato rhizosphere (Lee et al. 2020), soil, plants, rhizosphere, industrial environments, animals 
Table 3 Effect of seed treatment with bacterial endophytes on phenol content in wilt-infected plants of two chickpea varieties

\begin{tabular}{|c|c|c|c|c|c|c|c|c|}
\hline \multirow[t]{3}{*}{ Treatments } & \multicolumn{8}{|c|}{ Phenol content $(\mu \mathrm{g} / \mathrm{g})$} \\
\hline & \multicolumn{4}{|l|}{$\mathrm{HC} 3$} & \multicolumn{4}{|l|}{ JG 62} \\
\hline & Week1 & Week2 & Week3 & Mean & Week1 & Week2 & Week3 & Mean \\
\hline CRBE1 & 184.54 & 217.19 & 237.82 & 213.18 & 67.5 & 92.19 & 148.08 & 102.59 \\
\hline CRBE3 & 330.37 & 356.41 & 412.70 & 366.49 & 155.89 & 181.53 & 267.27 & 201.56 \\
\hline CRBE7 & 275.68 & 301.73 & 358.01 & 311.81 & 93.19 & 144.07 & 153.89 & 130.38 \\
\hline CRBE1 + CRBE3 & 233.61 & 259.66 & 315.95 & 269.74 & 117.63 & 163.70 & 146.07 & 142.47 \\
\hline CRBE1 + CRBE7 & 190.75 & 210.98 & 269.07 & 223.60 & 138.06 & 97.59 & 177.52 & 137.73 \\
\hline CRBE3 + CRBE7 & 286.70 & 312.74 & 369.03 & 322.82 & 186.74 & 118.83 & 200.36 & 168.64 \\
\hline CRBE1 + CRBE3 + CRBE7 & 199.16 & 212.78 & 273.48 & 228.47 & 94.79 & 121.23 & 175.12 & 130.38 \\
\hline Control & 79.97 & 104.61 & 160.9 & 115.16 & 64.14 & 88.38 & 144.67 & 99.06 \\
\hline Mean & 222.60 & 247.01 & 299.62 & & 114.74 & 125.94 & 176.62 & \\
\hline \multirow[t]{3}{*}{ C.D. $(p=0.05)$} & \multicolumn{4}{|c|}{ Week 4.83} & \multicolumn{4}{|l|}{7.32} \\
\hline & \multicolumn{4}{|c|}{ Treatment 7.38} & \multicolumn{4}{|l|}{11.18} \\
\hline & \multicolumn{4}{|c|}{ Week $\times$ Treatment 12.78} & 19.37 & & & \\
\hline
\end{tabular}

and humans (Hu et al. 2020). The results of the present study were in accordance with those of Lee et al. (2020) who reported plant growth-promoting activity of Brucella anthropi strain T16R-87 and Saini et al. (2017) who observed the ability of Ochrobactrum intermedium CP-2 chickpea isolate to produce siderophore. Endophytic bacterial isolate CRBE1, identified as Priestia megaterium in the present study, was previously known as Bacillus megaterium (Biedendieck et al. 2021), produced HCN along with ACC utilization, while isolate CRBE7 (Microbactrum haematophilum) showed positive reaction for siderophore and $\mathrm{HCN}$ production.

Under in vitro conditions, CRBE3 (Brucella haematophila) showed maximum mycelial inhibition (63.95\%) of F. oxysporum f. sp. ciceris. Similarly, Lee et al. (2020) reported that $B$. anthropi strain T16R-87 conferred resistance against bacterial wilt pathogen, Ralstonia solanacearum. Shoaib et al. (2020) reported antagonistic activity of Ochrobactrum ciceri in contending charcoal rot disease of mung bean. The other two isolates CBRE7 and CRBE1, also, showed pronounced antifungal activity against the test pathogen. Antagonistic activity of Priestia sp. against Fusarium wilt was also reported by Bashir et al. (2021) in sunflower. Rangeshwaran et al. 2002 also reported that under in vitro conditions, B. subtilis isolate PDBCEN 3 and Rb29 inhibited the mycelial growth of F. oxysporum f. sp. ciceris, while isolate $\mathrm{Rb} 29$ reduced the wilt incidence both in pot and field conditions. Kumari and Khanna (2018) recorded maximum control of mycelial proliferation of the pathogen with Ps16b (45.7\%) and Ps45 (87.3\%) in dual culture plate and liquid broth assay amongst 61 chickpea rhizosphere isolates, while Mukherjee et al. (2020) reported that amongst the isolates retrieved from chickpea seed, Pseudomonas aeruginosa BHUJPCS-7 showed significant antifungal activity against $F$. oxysporum f. sp. ciceris.

In the present study, seed priming with endophytic bacterial isolate CRBE3 curtailed the Fusarium disease severity in both the chickpea varieties and found to be superior as individual treatment rather combination or consortium. Maximum phenol content $(412.70 \mu \mathrm{g} / \mathrm{g})$ was observed in plants of chickpea variety $\mathrm{HC} 3$ raised from seed treated with CRBE3. Similarly, Maheshwari et al. (2019) reported that seed treatment with B. subtilis strain (CPHR3) was the most effective in promoting chickpea growth in pots under screen house conditions. Datta and Lal (2012) also correlated Fusarium wilt resistance with phenol content in chickpea varieties and observed maximum phenol content $\left(21.8 \mathrm{mg} \mathrm{gdw}{ }^{-1}\right)$ in wilt-resistant cultivars and minimum $\left(16.5 \mathrm{mg} \mathrm{gdw}^{-1}\right)$ in susceptible lines of chickpea.

The results of the present study highlighted the significance of sustainable agronomic practices for improving the crop yield, while reduction in the adverse effect of chemical pesticides through seed biopriming of chickpea with root endophytic bacteria was demonstrated.

\section{Conclusions}

It was concluded that the comprehensive diversity of endophytic bacteria from $C$. arietinum plants along with their plant growth promoted potential both in vitro and in vivo. Three effective multi-traits endophytes exhibited plant growth-promoting traits and bio-control potential against a devastating pathogen $F$. oxysporum f. sp. ciceris inciting Fusarium wilt. Such bio-control agents can be used as a component in integrated disease management 
for enhancing crop productivity and for safe and ecofriendly crop production.

\section{Abbreviation \\ CD: Critical difference.}

\section{Acknowledgements}

Authors are highly thankful to Dean Post Graduate Studies and Head Department of Plant Pathology, CCS Haryana Agricultural University, Hisar (Haryana), India, for providing facilitation to carry out research work. Studies involving plants must include a statement specifying the local, national or international guidelines and legislation and the required or appropriate permissions and/or licences for the study (if applicable): Not applicable in the study

\section{Authors' contributions}

AK contributed to conductance, data collection and writing original manuscript. KR contributed to conceptualization, planning, monitoring and editing, PK contributed to statistical analysis, and LW endophyte identification and editing. All authors proofread and approved the final manuscript.

\section{Funding}

No special funding was obtained for this study.

\section{Availability of data and materials}

All data generated or analysed in this study are available in this manuscript.

\section{Declarations}

\section{Ethics approval and consent to participate}

Not applicable.

\section{Consent for publication}

This study does not contain any individual person's data and authors consent for publication.

\section{Competing interests}

The authors declare that they have no competing interests.

\section{Author details}

'Department of Plant Pathology, College of Agriculture, CCS Haryana Agricultural University, Hisar, Haryana Pin 125 004, India. ${ }^{2}$ Department of Floriculture and Landscaping, Punjab Agricultural University, Ludhiana 141 004, Punjab, India. ${ }^{3}$ Department of Microbiology, COBS\&H, CCS Haryana Agricultural University, Hisar, Haryana Pin 125 004, India.

Received: 24 October 2021 Accepted: 15 February 2022

Published online: 22 February 2022

\section{References}

Alstrom S, Burns RG (1989) Cyanide production by rhizobacteria as a possible mechanism of plant growth inhibition. Bio Fert Soils 7:232-238. https:// doi.org/10.1007/BF00709654

Bahmani K, Hasanzadeh N, Harighi B, Marefat A (2021) Isolation and identification of endophytic bacteria from potato tissues and their effects as biological control agents against bacterial wilt. Physiol Mol Plant Pathol 116:101692. https://doi.org/10.1016/j.pmpp.2021.101692

Bashir S, lqbal A, Hasnain S, White JF (2021) Screening of sunflower associated bacteria as biocontrol agents for plant growth promotion. Arch Microbiol. https://doi.org/10.1007/s00203-021-02463-8

Batra P, Barkodia M, Ahlawat U, Sansanwal VRK, Wati L (2020) Identification and characterization of promising endophytic bacteria for growth promotion in chickpea (Cicer arietinum). Indian J Agric Sci 90(4):708-712

Biedendieck R, Knuuti T, Moore SJ, Jahn D (2021) The "beauty in the beast" — the multiple uses of Priestia megaterium in biotechnology. Appl Microbiol Biotechnol. https://doi.org/10.1007/s00253-021-11424-6
Cheng T, Yao XZ, Wu CY, Zhang W, He W, Dai CC (2020) Endophytic Bacillus megaterium triggers salicylic acid-dependent resistance and improves the rhizosphere bacterial community to mitigate rice spikelet rot disease. Appl Soil Ecol 156:103710. https://doi.org/10.1016/j.apsoil. 2020.103710

Datta J, Lal N (2012) Temporal and spatial changes in phenolic compounds in response to Fusarium wilt in chickpea and pigeonpea. Cell Mol Biol 58(1):96-102

Dubey SC, Suresh M, Singh B (2007) Evaluation of Trichoderma species against Fusarium oxysporum $\mathrm{f}$. sp. ciceris for integrated management of chickpea wilt. Biol Control 40:118-127. https://doi.org/10.1016/j.bioco ntrol.2006.06.006

Dworkin M, Foster J (1958) Experiments with some microorganisms which utilize ethane and hydrogen. J Bacteriol 75:592-601

Halila MH, Strange RN (1996) Identification of the causal agent of wilt of chickpea in Tunisia as Fusarium oxysporum f. sp. ciceri race. Phytopathol Medit 35:67-74

Holt JG, Krieg NR, Sneath PH, Staley JT, Williams ST (1994) Bergey's manual of determinative bacteriology, 9th edn. The Williams and Wilkins Co, Baltimore

Hördt A, López MG, Meier-Kolthoff JP, Schleuning M, Weinhold LM, Tindall BJ, Gronow S, Kyrpides NC, Woyke T, Göker M (2020) Analysis of 1,000+ type-strain genomes substantially improves taxonomic classification of Alphaproteobacteria. Front Microbiol 7(11):468. https://doi.org/10 3389/fmicb.2020.00468

https://www.statista.com/statistics/722203/chickpeas-production-volumeby-country-worldwide/

Hu M, Li X, Li Z, Liu B, Yang Z, Tian Y (2020) Ochrobactrum teleogrylli sp. Nov., a pesticide-degrading bacterium isolated from the insect Teleogryllus occipitalis living in deserted cropland. Int J Syst Evol Microbiol 70(4):2217-2225. https://doi.org/10.1099/ijsem.0.003964

Jiménez-Díaz RM, Castillo P, del Mar J-G, Landa BB, Navas-Cortés JA (2015) Fusarium wilt of chickpeas: Biology, ecology and management. Crop Prot 73:16-27. https://doi.org/10.1016/j.cropro.2015.02.023

Khanna A, Raj K, Gandhi V (2019) Construing the role of endophytes in forage and other crops disease management. Forage Res 45(3):173-182

Kumar S, Stecher G, Li M, Knyaz C, Tamura K (2018) MEGA X: molecular evolutionary genetics analysis across computing platforms. Mol Biol Evol 35(6):1547. https://doi.org/10.1093/molbev/msy096

Kumari S, Khanna V (2018) Biological management of vascular wilt of chickpea (Cicer arietinum L.) incited by Fusarium oxysporum f. sp. ciceris by antagonistic rhizobacteria co-inoculated with native Mesorhizobium. Int J Curr Microbiol Appl Sci 7(1):920-941. https://doi.org/10.20546/ ijcmas.2018.701.112

Lee SA, Sang MK, Song J, Kwon SW, Weon HY (2020) Complete genome sequence of Brucella anthropi strain T16R-87 isolated from tomato (Solanum lycopersicum L.) rhizosphere. Korean J Microbiol 56(4):430432. https://doi.org/10.7845/kjm.2020.0116

Maheshwari R, Bhutani N, Bhardwaj A, Suneja P (2019) Functional diversity of cultivable endophytes from Cicer arietinum and Pisum sativum: bioprospecting their plant growth potential. Biocatal Agric Biotechnol 20:101229. https://doi.org/10.1016/j.bcab.2019.101229

Mukherjee A, Singh BK, Verma JP (2020) Harnessing chickpea (Cicer arietinum L.) seed endophytes for enhancing plant growth attributes and bio-controlling against Fusarium sp. Microbiol Res 237:126469. https:// doi.org/10.1016/j.micres.2020.126469

Nagpal S, Sharma P, Sirari A, Kumawat KC, Wati L, Gupta SC, Mandahal KS (2021) Chickpea (Cicer arietinum L.) as model legume for decoding the co-existence of Pseudomonas fluorescens and Mesorhizobium sp. as biofertilizer under diverse agro-climatic zones. Microbiol Res 247:126720. https://doi.org/10.1016/j.micres.2021.126720

Pan D, Mionetto A, Tiscornia S, Bettucci L (2015) Endophytic bacteria from wheat grain as biocontrol agents of Fusarium graminearum and deoxynivalenol production in wheat. Mycotoxin Res 31(3):137-143. https:// doi.org/10.1007/s12550-015-0224-8

Panse VG, Sukhatame PV, Sukhatame PV, Amble VN (1978) Statistical method for agricultural workers, 3rd, revised edn. New Delhi, ICAR, $p$ 347

Penrose DM, Glick BR (2003) Methods for isolating and characterizing ACC deaminase- containing plant growth-promoting rhizobacteria. Physiol Plants 118(1):10-15. https://doi.org/10.1034/j.1399-3054.2003.00086.x 
Rangeshwaran R, Wasnikar AR, Prasad RD, Anjula N, Sunanda CR (2002) Isolation of endophytic bacteria for biological control of wilt pathogens. J Biol Control 16(2):125-134

Rangeshwaran R, Raj J, Kumar S (2008) Identification of endophytic bacteria in chickpea (Cicer arietinum L.) and their effect on plant growth. J Biol Control 22:13-23

Saini A, Nain L, Garg V, Saxena J (2017) Improvement of growth, yield, and pigmentation of mung bean plants using Ochrobactrum intermedium CP-2 as bioinoculant. Clean: Soil, Air, Water 45(6):1500670. https://doi.org/ 10.1002/clen.201500670

Saini R, Kumar V, Dudeja SS, Pathak DV (2015) Beneficial effects of inoculation of endophytic bacterial isolates from roots and nodules in chickpea. Int J Curr Microbiol Appl Sci 4(10):207-221

Sangwan P, Raj K, Wati L, Kumar A (2021) Isolation and evaluation of bacterial endophytes against Sclerospora graminicola (Sacc.) Schroet, the causal of pearl millet downy mildew. Egypt J Biol Pest Control 31(1):1-1. https:// doi.org/10.1186/s41938-021-00468-5

Schwyn B, Neilands JB (1987) Universal chemical assay for the detection and determination of siderophore. Ann Biochem 160:47-56. https://doi.org/ 10.1016/0003-2697(87)90612-9

Shoaib A, Ali H, Javaid A, Awan ZA (2020) Contending charcoal rot disease of mungbean by employing biocontrol Ochrobactrum ciceri and zinc. Physiol Mol Biol Plants 26(7):1385-1397. https://doi.org/10.1007/ s12298-020-00817-y

Thimmaiah SK (2006) A text book of standard methods of biochemical analysis. Kalyani Pub, New Delhi

Vincent JM (1947) Distortion of fungal hyphae in presence of certain inhibitors. Nature 150:850. https://doi.org/10.1038/159850b0

Volpiano CG, Sant'Anna FH, Ambrosini A, Lisboa BB, Vargas LK, Passaglia LMP (2019) Reclassification of Ochrobactrum lupini as a later heterotypic synonym of Ochrobactrum anthropi based on whole-genome sequence analysis. Int J Syst Evol Microbiol 69(8):2312-2314. https://doi.org/10. 1099/ijsem.0.003465

Weisburg WG, Barns SM, Pelletier DA, Lane DJ (1991) 16S ribosomal DNA amplification for phylogenetic study. J Bacteriol 173(2):697-703. https:// doi.org/10.1128/jb.173.2.697-703.1991

\section{Publisher's Note}

Springer Nature remains neutral with regard to jurisdictional claims in published maps and institutional affiliations.

\section{Submit your manuscript to a SpringerOpen ${ }^{\circ}$ journal and benefit from:}

- Convenient online submission

- Rigorous peer review

- Open access: articles freely available online

- High visibility within the field

- Retaining the copyright to your article 